\title{
„Przypomnij sobie...” (Ap 2,5; 3,3) Duch Święty żywą pamięcią Kościoła w świetle Apokalipsy Janowej
}

\author{
"Remember..." (Rev 2:5; 3:3). The Holy Spirit as the Church's Living Memory \\ according to the Revelation of John
}

\section{PAWE PODESZWA}

Uniwersytet im. Adama Mickiewicza w Poznaniu

podpaw@amu.edu.pl, ORCID: 0000-0002-4000-1660

\begin{abstract}
Streszczenie: Duch Święty przypomina Kościołowi wszystko, co Jezus powiedział i uczynił. Dwa teksty z Apokalipsy Janowej wskazują wyraźnie na tę funkcję Parakleta, który mówi do wspólnoty, odwołując się jednocześnie do jej pamięci: w Liście do Kościoła w Efezie $(2,5)$ oraz w Liście do Kościoła w Sardach $(3,3)$. Oba pisma zawierają imperatyw „przypomnij sobie”. W ich świetle staramy się odpowiedzieć na podstawowe pytanie: o czym Duch Święty przypomina Kościołowi? Analizowane teksty, w których Duch Święty wzywa wspólnotę Kościoła do pobudzenia pamięci, wyraźnie wskazują, że chodzi przede wszystkim najpierw o przypomnienie fundamentów chrześcijańskiej wiary (Wcielenie, misterium paschalne) oraz tożsamości chrześcijan, przez chrzest złączonych z ukrzyżowanym i zmartwychwstałym Jezusem i zrodzonych do nowego życia. Wezwanie do pamiętania jest równoznaczne z koniecznością gorliwego strzeżenia depozytu wiary oraz nawracania się, to znaczy przyjmowania mentalności i zamysłu samego Boga, co dalej ma owocować konkretnymi czynami wiary. Motywacją do takiej postawy chrześcijan jest pamięć o dobrodziejstwach i darach Boga. Duch Święty, nazywany przez Katechizm Kościoła Katolickiego „żywą pamięcią Kościoła” (1099), pobudzając i aktywując pamięć wspólnoty, mobilizuje do żywej i owocującej wiary, która wyraża się w prawdziwym chrześcijańskim świadectwie przynależności do Jezusa, braterskiej miłości oraz gorliwym głoszeniu Dobrej Nowiny.
\end{abstract}

Słowa klucze: Apokalipsa; List do Kościoła w Efezie; List do Kościoła w Sardach; Duch Święty; pamięć; nawrócenie; depozyt wiary

Abstract: The Holy Spirit reminds the Church about everything that Jesus said and did. Two texts from the Book of Revelation clearly point to this function of the Paraclete, who speaks to the community, at the same time referring to its memory. The texts are from the Letter to the Church in Ephesus (2:5) and the Letter to the Church in Sardis (3:3), both containing an imperative to "remember." In their light, we attempt to answer the basic question: What does the Holy Spirit remind the Church about? The analyzed texts, in which the Holy Spirit calls upon the Church community to stimulate memory, clearly indicate that the main issue, first and foremost, is remembering the foundations of the Christian faith (Incarnation, paschal mystery) and the identity of Christians united, through baptism, with the crucified and risen Jesus and born into a new life. The call for remembering expresses the fundamental need to eagerly guard the repository of faith and conversion, that is, to accept God's intention and plan, which ought to lead to concrete acts of faith. The motivation for such an attitude on the part of Christians is the memory of God's kindness and gifts. The Holy Spirit, called by The Catechism of the Catholic Church "the Church's living memory" (1099), as it stimulates and activates the memory of the community, will mobilize believers to a living and fruitful faith. This in turn is ex- 
pressed in a true Christian testimony of belonging to Jesus, brotherly love, and zealous proclamation of the Good News.

Keywords: Revelation; Letter to the Church in Ephesus; Letter to the Church in Sardis; Holy Spirit; memory; conversion; deposit of faith

W Ewangelii według św. Jana czytamy obietnicę Jezusa odnoszącą się do Ducha Świętego: „A Paraklet - Duch Święty, którego Ojciec pośle w moim imieniu, pouczy was o wszystkim oraz przypomni wszystko, co wam powiedziałem" $(14,26)$. Stąd Katechizm Kościoła Katolickiego, nawiązując do powyższych słów Chrystusa, nazywa trzecią Osobę Trójcy Świętej „żywą pamięcią Kościoła” (1099). Wśród tekstów biblijnych Nowego Testamentu, które bezpośrednio wskazują na tę właśnie funkcję Parakleta ${ }^{1}$, należy wymienić zwłaszcza dwa fragmenty z ostatniej księgi kanonu, to znaczy Apokalipsy Janowej. Oba znajdują się w jej epistolarnej części: w Liście do Kościoła w Efezie $(2,5)$ oraz w Liście do Kościoła w Sardach $(3,3)$ i zawierają imperatyw „przypomnij sobie” ( $\mu \nu \eta \mu o ́ v \in \cup \epsilon)^{2}$, wypowiedziany wprost przez Ducha Świętego ${ }^{3}$ do wspólnoty Kościoła ${ }^{4}$. Teksty te stanowić będą przedmiot analizy, w świetle której postaramy się odpowiedzieć na podstawowe pytanie: o czym Duch Święty przypomina Kościołowi?

\section{Chrystus i Duch mówi do Kościoła}

Po prologu Apokalipsy (1,1-3), początkowym dialogu liturgicznym (1,4-8) i wizji wstępnej (1,9-20) czytamy listy do siedmiu Kościołów (2,1-3,22), napisane przez Jana zgodnie z otrzymanym wcześniej poleceniem: „To, co widzisz, opisz w księdze i prześlij do siedmiu Kościołów: do Efezu, Smyrny, Pergamonu, Tiatyry, Sard, Filadelfii i Laodycei" (1,11). Warto od razu zauważyć, że sam autor informuje nas, że nakaz ten

1 Termin „Paraklet” jest własnym wyrażeniem Ewangelisty Jana, wpisanym w teologię jego dzieła. W Apokalipsie się nie pojawia, ale mowa jest o specyficznych funkcjach Janowego Parakleta i w tym znaczeniu używam go także w artykule, pisząc o Paraklecie w ostatniej księdze Nowego Testamentu.

2 Czasownik $\mu \nu \eta \mu \nu \nu \in u ́ \omega$ - „pamiętać, przypominać sobie o czymś, wspominać coś”; zob. Popowski, Wielki słownik, 401, występuje 21 razy w Nowym Testamencie (Mt 16,9; Mk 8,18; Łk 17,32; J 15,20; 16,4.21; Dz 20,31.35; Ga 2,10; Ef 2,11; Kol 4,18; 1 Tes 1,3; 2,9; 2 Tes 2,5; 2 Tm 2,8; Hbr 11,15.22; 13,7; Ap 2,5; 3,$3 ; 18,5$. Na temat innych czasowników i rzeczowników związanych z pamięcią w Nowym Testamencie zob. Podeszwa, Paschalna pamięć, 48.

3 Tylko w Ap 2,5 i 3,3 podmiotem mówiącym jest Duch Święty. W Ap 18,5 czytamy natomiast o Bogu, który pamięta o występkach Babilonii. O pamięci Boga jest też mowa w Ap 16,19: „Bóg przypomniał

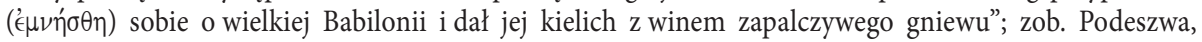
Paschalna pamięć, 51-52; choć tutaj został użyty czasownik $\mu \iota \mu v \underline{́ \sigma \kappa o \mu \alpha \iota ~-~ „ p r z y p o m i n a c ́ ~ s o b i e, ~ p a m i e ̨ t a c ́, ~}$ myśleć o czymś; pass. być wspomnianym przed Bogiem”; zob. Popowski, Wielki słownik, 400.

4 Zob. Wojciechowski, Apokalipsa, 127. 
otrzymał w „dzień Pański”, to znaczy w niedzielę ${ }^{5}$, gdy „znalazł się w Duchu” $(1,10)$, to jest pod natchnieniem i kontrolą Ducha Świętego ${ }^{6}$. Otrzymawszy „Objawienie Jezusa Chrystusa” $(1,1)$, sam stał się jego wiarygodnym świadkiem, aby przekazać je wymienionym wspólnotom kościelnym, które ostatecznie oznaczają cały Kościół, na co wskazuje symboliczne użycie liczby siedem ${ }^{7}$. W ten sposób wszystko, co zostało spisane, jest dziełem Ducha Świętego, a „Objawienie Jezusa Chrystusa” staje się „Objawieniem w Duchu Świętym"8.

Potwierdza to jednoznacznie lektura siedmiu listów Apokalipsy. Są one zbudowane według stałego schematu, w którym można wyróżnić siedem elementów: 1) adres; 2) nakaz napisania; 3) autoprezentacja Jezusa; 4) osąd wspólnoty; 5) wezwanie szczegółowe; 6) wezwanie ogólne; 7) obietnica nagrody dla zwycięzcy. W kontekście naszych dociekań interesuje nas szczególnie zależność między trzecim a szóstym elementem, to znaczy między autoprezentacją Chrystusa zmartwychwstałego a wezwaniem ogólnym, które brzmi zawsze tak samo: „kto ma ucho, niech słucha, co mówi Duch do Kościołów" (2,7.11.17.29; 3,6.13.22), i w czterech przypadkach kończy list $(2,29 ; 3,6.13 .22)^{9}$. Podmiotem czynności mówienia na początku każdego listu jest

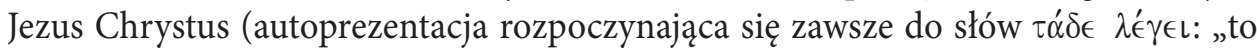
mówi...” w 2,1.8.12.18; 3,1.7.14), na końcu listu podmiotem jest zaś Duch Święty ( zarówno rodzajnik określony odnoszący się do Ducha, jak i wyrażona funkcja mówienia, która podkreśla Jego charakter osobowy. Przypisanie tej samej czynności Jezusowi i Duchowi Świętemu nie tylko akcentuje równość Osób Boskich i jest elementem, charakterystycznej dla Apokalipsy, chrystologii pneumatologicznej, ale pozwala traktować słowa Jezusa jako słowa Ducha Świętego i odwrotnie. W każdym liście są zatem „słyszalne” słowa Jezusa, ale do Kościoła „tu i teraz” mówi nie kto inny, jak Duch Święty, który przypomina i prowadzi do pełni prawdy (zob. J 16,13-14) ${ }^{10}$. Jest to to samo objawienie, które dzięki Duchowi Świętemu pozostaje żywe i ciągle aktualizowane w dziejach Kościoła ${ }^{11}$. Zauważmy także, że formuła „kto ma ucho, niechaj słucha, co mówi Duch do Kościołów", która kończy poszczególne listy, używa liczby

5 Zob. Lijka, „Dzień Pański”, 33-39.

6 Zob. Kotecki, Duch Święty, 297-299; Kempiak, „Pneumatologia”, 141-142. Inaczej twierdzi Michał Wojciechowski (Apokalipsa, 114), którego zdaniem wyrażenie to nie wskazuje na działanie osobowe, na wpływ Ducha Bożego, lecz na stan natchnienia prorockiego. Stąd „odniesienie do Ducha Bożego może być więc tutaj tylko pośrednie i domniemane".

7 Zob. Biguzzi, „I numeri nell’Apocalisse”, 143-166; Díez Merino, „La numerología”, 59-98; Marconi, Le mille immagini, 64-75; Corsini, „I numeri nell'Apocalisse”, 391-416; Zbroja, „Symbolika arytmetyczna”, 131-158; Podeszwa, „Il simbolismo”, 85-101.

8 Zob. R. Kempiak, „Pneumatologia”, 142.

9 Ostatnie dwa elementy czasami zamienione są kolejnością. Szczegółowe omówienie struktury listów, zob. Tkacz, Listy do siedmiu Kościołów, 49-58.

10 Moriconi, Lo Spirito, 188.

11 Zob. Kotecki, „List do Kościoła”, 262. 
mnogiej „Kościołów”. Oznacza to, że słowa wypowiedziane przez Ducha Świętego do poszczególnych siedmiu Kościołów lokalnych (Efezu, Smyrny, Pergamonu, Tiatyry, Sard, Filadelfii i Laodycei) są jednocześnie przesłaniem skierowanym do wszystkich Kościołów lokalnych, czyli całego Kościoła powszechnego ${ }^{12}$, co potwierdza także symbolizm arytmetyczny liczby „siedem”, o czym była już mowa wcześniej. Słusznie zatem stwierdza Ryszard Kempiak:

Można powiedzieć, że odległość między Chrystusem i Kościołem zostaje zniwelowana przez głos Ducha Świętego. W życiu ziemskim Jezus mówił i wyjaśniał swoje przesłanie, teraz zaś czyni to za pośrednictwem Ducha Świętego. W Kościele jest obecny Duch, który kontynuuje funkcję objawieniową i wyjaśniającą samego Jezusa. On jest jednym interpretatorem całego przesłania Jezusa. [...] Duch Święty, który mówi, jest Duchem proroctwa. Przekazuje On przez Jana to, co mówi Jezus. Przez Ducha Świętego głos Jezusa, Jego wola są obecne w Kościele ${ }^{13}$.

\section{Kościół zasłuchany w mowę Ducha Świętego}

Skoro Duch Święty przekazuje i aktualizuje objawienie Jezusa Chrystusa, konieczne jest, aby uczniowie Jezusa usłyszeli to, co Duch Święty mówi do Kościoła ${ }^{14}$. Księgę Apokalipsy otwiera pierwsze błogosławieństwo: „Błogosławiony, który odczytuje i którzy słuchają słów proroctwa” $(1,3)$, ściśle łączące się z siedmiokrotnie powracającym wezwaniem: „kto ma ucho, niechaj słucha, co mówi Duch do Kościołów”, w zakończeniu siedmiu listów do Kościołów. Jak słusznie zauważa Dariusz Kotecki:

wezwanie, mimo że dotyczy Kościołów, to jednak jest skierowane do poszczególnych członków wspólnoty, dokładnie do tego, „kto ma ucho”, bo tylko on jest zdolny do słuchania. Chodzi o słuchanie permanentne (stąd imiesłów czasu teraźniejszego „echōn”). Wezwanie do takiego słuchania ma charakter kategoryczny (stąd tryb rozkazujący aorystu „akousatōn”) ${ }^{15}$.

Ponieważ w Biblii Starego Testamentu ucho było nie tylko organem słuchu, ale także, a może przede wszystkim, świadomości, zrozumienia i inteligencji (por. Hi 12,11; 13,1; 34,3; Prz 2,2; 5,13; 18,15; 22,17; 23,12), wyrażenie „mieć ucho” oznacza umiejętność słuchania, percepcji, uwagi, przyswajania i wypełniania tego,

\footnotetext{
Na temat eklezjologii Apokalipsy zob. Kotecki, Kościół; Podeszwa, „Wspólnota Kościoła”, 55-69.

Kempiak, „Pneumatologia”, 146; zob. także Manunza, L’Apocalisse, 277.

Zob. de Lassus, L'Église.

Kotecki, „List do Kościoła w Laodycei”, 262.
} 
czego słowo naucza. Prawdziwe słuchanie obejmowało więc usłyszenie, zrozumienie oraz ostatecznie danie posłuchu słowu, to znaczy posłuszeństwo. Kiedy wspólnota słyszy to wezwanie, wie, że chodzi o pewną duchową dyspozycję otwarcia się na słuchane słowo, ale także:

o zdolność interpretacji tego, co się usłyszało, do odszyfrowania wszystkiego, co w pierwszym momencie wydaje się niezrozumiałe. Słuchacz zostaje w ten sposób pobudzony do słuchania przesłania Ducha Świętego, przekazującego słowa samego Jezusa. Duch mówi na sposób ludzki, który domaga się od słuchających zaangażowania wszystkich sił intelektualnych służących do interpretacji, zrozumienia, refleksji. Jeżeli jedynym interpretatorem tego przesłania jest Duch Święty, to przez wezwanie „Kto ma ucho niechaj posłyszy, co mówi Duch do Kościołów" zgromadzenie jest zobligowane do tego, by odkrywać w całym przesłaniu listów to, co chciał przekazać Duch Święty. Chodzi o otrzymanie „inteligencji pneumatycznej", która pozwoli wierzącym odkryć całą głębię, znaczenie słów. Dawcą takiej inteligencji może być tylko Duch Święty, dlatego można mówić w tym miejscu o „duchowym słuchaniu” lub „duchowym zrozumieniu”16.

O czym zatem przypomina Duch Święty Kościołowi?

\section{Przypomnij sobie, skąd spadłeś... $(2,5)$}

Pierwsze wyraźne odwołanie się do pamięci wspólnoty znajdujemy w Liście do Kościoła w Efezie ${ }^{17}(2,1-7)$. List skierowany jest wprost do „anioła Kościoła w Efezie” $(2,1)$, to znaczy do przełożonego wspólnoty, ale ostatecznym adresatem jest cała wspólnota, a nie tylko jej reprezentant ${ }^{18}$. Jezus przedstawia się wspólnocie efeskiej jako „Ten, który trzyma siedem gwiazd w swojej prawej ręce, który chodzi pośród siedmiu świeczników" $(2,1)$. Jest to wyraźne nawiązanie do wizji inauguracyjnej (1,9-20, a zwłaszcza 1,13), gdzie Jan wspomina, że zobaczył „pośród świeczników kogoś podobnego do Syna Człowieczego”, kto „ma w swojej prawej ręce siedem gwiazd” $(1,16)$. Zakończenie wstępnej wizji przynosi nam wyjaśnienie powyższej symboliki: „co do tajemnicy siedmiu gwiazd, które zobaczyłeś na mojej prawicy, i siedmiu złotych świeczników: siedem gwiazd to aniołowie siedmiu Kościołów, a siedem świeczników to siedem Kościołów" $(1,20)$. W pierwszym liście Jezus przedstawia się zatem jako Pan kosmosu i Kościoła (gwiazdy), obecny „pośrodku” $(1,13)$

\footnotetext{
16 Kotecki, „List do Kościoła w Laodycei”, 262.

17 Na temat historii miasta, lokalnej społeczności żydowskiej i chrześcijańskiej, topografii Efezu oraz danych archeologicznych zob. Tkacz, Listy do siedmiu Kościołów, 81-98; Bogacz, Chrystusowe wskazania, 10-28. 
swojej wspólnoty. Według Ap 2,1 jest On „przechadzającym się pośród siedmiu świeczników". W ten sposób zostaje podkreślona Jego nieustanna, ciągła i czynna (czas teraźniejszy imiesłowu) obecność w Kościele ${ }^{19}$.

Centralna pozycja Jezusa w Kościele oznacza także, że zna On doskonale sytuację poszczególnych wspólnot i zarazem Kościoła powszechnego. Dlatego kolejny element listu to osąd wspólnoty efeskiej (2,2-4). Rozpoczyna się od Jezusowego „znam twoje czyny". Osąd Jezusa oparty jest zatem na rozeznaniu rzeczywistej sytuacji adresatów listu. Wspólnota efeska zostaje najpierw pochwalona za „trud i wytrwałość” ${ }^{20}$ pośród różnych przejawów zewnętrznej wrogości ze strony pogan, praktykujących kult bogini Artemidy (zob. Dz 19,23-39) oraz kult imperialny, zwłaszcza cesarza Domicjana, który zbudował w Efezie świątynię i kazał czcić siebie jako „naszego Pana i naszego Boga" ${ }^{21}$. Nie było to jednak jedyne zagrożenie wspólnoty efeskiej. Jezus pochwalą ją za także za to, że nie mogła „znieść złych” i poddała próbie „tych, którzy uważają się za apostołów, a nimi nie są”, i uznała „ich za kłamców” $(2,2)$. Wyrażenia te wskazują, że chodzi o fałszywych i samozwańczych apostołów, którzy poprzez swoje nauczanie wprowadzali ogromny zamęt doktrynalny i moralny we wspólnocie. Trudno jednoznacznie stwierdzić, jakie fałszywe poglądy szerzyły się w Efezie. Najczęściej wymienia się różnego rodzaju prądy myślowe zabarwione gnostycko ${ }^{22}$, działalność tzw. judaizujących ${ }^{23}$ lub nikolaitó $w^{24}$, o których mowa dalej, że ich postępowania nienawidzi wspólnota, podobnie jak i sam Jezus $(2,6)^{25}$. Wobec trudności zarówno wewnętrznych, jak i zewnętrznych, wspólnota okazała się wytrwała i - mimo cierpień (różnego rodzaju prześladowań ${ }^{26}$ ) dla imienia Jezus - nie osłabła w swoim trudzie i wytrwałości, stąd zasługuje na miano „niestrudzonej” $(2,3)$.

19 Zob. Kotecki, Duch Święty, 202.

20 Zob. Karczewski, „Wytrwałość chrześcijan”, 192-204.

21 Zob. Chrostowski, Entuzjazm, 33.

22 Zob. Wojciechowski, Apokalipsa, 128.

23 Zob. Chrostowski, Entuzjazm, 33.

24 Zob. Sikora, „[..] odstąpiłeś od twej pierwotnej miłości”, 172.

25 Na temat nikolaitów zob. Kotecki, Duch Święty, s. 106-113. Łączenie fałszywych proroków z nikolaitami wydaje się mało prawdopodobna; zob. Tkacz, Listy do siedmiu Kościołów, 104-107; Bogacz, Chrystusowe wskazania, 38 i przyp. 1.

Bogacz, Chrystusowe wskazania, 40-41: „Prawdopodobnie chodzi tu o prześladowania, których doświadczyli Efezjanie ze względu na samego Chrystusa, bo tak należy rozumieć zwrot «dla imienia mego». Pierwsze krwawe represje, jakie dotknęły chrześcijan miały miejsce za czasów Nerona, jednak dotyczyły Rzymu i okolic, a spowodowane były politycznymi problemami cesarza. Natomiast dużo bardziej krwawe i znacznie bardziej rozpowszechnione prześladowania nastąpiły za cesarza Domicjana, który nie zadowolił się powszechnie panującym przekonaniem o boskim pochodzeniu cesarzy i zarządził konieczność oddawania sobie kultu, wyznaczając śmierć jako karę za nieposłuszeństwo. Oddawanie czci cesarzowi było nie do przyjęcia dla chrześcijan, a zaistniała sytuacja doprowadziła do krwawych prześladowań. Lecz «znoszenie cierpień dla imienia» Chrystusa nie wyrażało się tylko w tak drastyczny sposób, jakim było męczeństwo. Chrześcijanie znajdowali się też w trudnej dla siebie sytuacji społecznej i gospodarczej: nie uznając wielobóstwa nie uczestniczyli w powszechnych obrzędach religijnych, co przekładało się na ich nieobecność w publicznym życiu kulturalnym i rozrywkowym, a także powodowało 
Jest jednak coś, co wyraźnie trapi wspólnotę efeską: porzuciła ona pierwotną miłość $(2,4)$, to znaczy odeszła od entuzjazmu, zapału oraz gorliwości w praktykowaniu Ewangelii. Być może z czasem osłabło zaangażowanie, wkradła się rutyna i przyzwyczajenie, i to wszystko razem pogorszyło jakość chrześcijańskiej miłości, zarówno względem samego Jezusa, który pierwszy umiłował (zob. 1,5) ${ }^{27}$, jak i braci. Nie jest wykluczone, że ową utratę pierwotnej miłości, zwłaszcza tej braterskiej, należy wiązać ze sporami i podziałami wywołanymi w Efezie z powodu nauczania przez fałszywych apostołów ${ }^{28}$, co prowadzić mogło do wyłączenia ze wspólnoty tych, którzy zostali osądzeni i uznani za niedoskonałych ${ }^{29}$.

W tej sytuacji Kościół w Efezie otrzymuje konkretne polecenie, składające się z trzech następujących po sobie imperatywów: „przypomnij więc sobie, skąd spa-

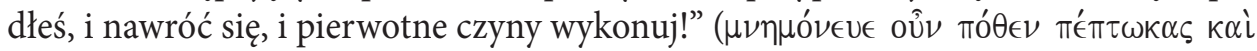

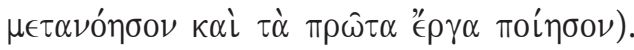

Pierwszy nakaz odwołuje się do pamięci wspólnoty, która ma sobie przypomnieć

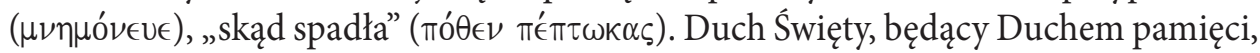
najpierw wzywa do przywołania w pamięci przeszłości, to znaczy źródeł wiary chrześcijańskiej. W zagadkowym wyrażeniu „skąd spadłeś” skierowanym do Kościoła efeskiego jest ukryta aluzja do mitu, według którego posąg Artemidy miał spać z nieba. Jest to zatem przypomnienie początku kultu bogini płodności w Efezie ${ }^{30}$. Analogicznie wspólnota chrześcijańska zostaje wezwana do pamięci o swoim początku, to znaczy nie tylko uświadomienia sobie, jak bardzo odeszła od pierwotnej miłości ${ }^{31}$, ale przede wszystkim przypomnienia sobie na nowo tego wszystkiego, co stanowiło początek wiary chrześcijańskiej i pozostaje jej niezmiennym fundamentem. Jest to aluzja do dwóch podstawowych prawd wyznawanych przez chrześcijan: wcielenie Syna Bożego i Jego misterium paschalne ${ }^{32}$. To jest źródło chrześcijańskiej wiary, jednak

ograniczenie możliwości zawodowych, gdyż cechy rzemieślnicze miały za swoich patronów pogańskich bogów, którym oddawały cześć. Nic więc dziwnego, że chrześcijanie mogli się czuć wyobcowani, spotykali się z podejrzliwością, wrogością, a nawet aktami nienawiści i niejednokrotnie stanowili uboższą część społeczeństwa. Jednakże chrześcijanie z Efezu w tych trudnych warunkach wykazali się wytrwałością w wierze i sposobie życia, a dla podkreślenia tej zalety zostali dodatkowo nazwani «nieutrudzonymi»".

27 Zob. Podeszwa, „Temu, który nas miłuje”, 95-110; zob. także Prigent, L’Apocalypse, 121; Sikora, „[..] odstąpiłeś od twej pierwotnej miłości", 173-176.

28 Zob. Aune, Revelation, 146.

29 Zob. Pottier - Struyf, „Lettres aux Églises”, 562.

30 Zob. Chrostowski, Entuzjazm, 34; Bogacz, Chrystusowe wskazania, 43-44 i przyp. 163. Inaczej Sikora, „[..] odstąpiłeś od twej pierwotnej miłości”, 177: „Sformułowanie to staje się zrozumiałe, jeśli pamięta się, że Kościół jest ukazany jako «gwiazda» (Ap 1,16; 2,1). Księga Apokalipsy zna bowiem myśl o spadających gwiazdach (Ap 6,13; 8,10[bis]; 9,1). Wspólnota efeska wypadła «z prawicy» Chrystusa z powodu osłabienia miłości. Czas przeszły (perfectum) wskazuje na to, że stan taki trwa, a samo znaczenie terminu, że zmiana, jaka nastąpiła w postawie wspólnoty, musiała być gwałtowna”.

31 Zdaniem Franciszka Siega (Apokalipsa, 65) zmiana postępowania wspólnoty efeskiej nastąpiła bardzo szybko, „gdyż skąd wskazuje na szczyt, z którego nastąpił głęboki upadek”.

32 Zob. Chrostowski, Entuzjazm, 34. Warto także zauważyć, że zasadniczo to do tych wydarzeń czyni symboliczne aluzja Apokalipsa (1,5.7; 2,8; 5,6.9; 7,14; 12,5; 19,13); zob. Podeszwa, Paschalna pamięć, 329-332. 
nie tylko w sensie teoretycznym, ale przede wszystkim egzystencjalnym. To z tych zbawczych wydarzeniach wypływa tożsamość chrześcijan, o której nigdy nie wolno zapomnieć. Przez chrzest święty chrześcijanie zostali włączeni w misterium paschalne, uwolnieni z grzechów $(1,5)$ oraz zrodzeni do nowego życia, aby stać się dziećmi Bożymi $^{33}$ oraz „Zwycięzcami” na wzór samego Jezusa.

Owo przypominanie, które jest charakterystycznym elementem także innych tekstów Nowego Testamentu, zwłaszcza o charakterze parenetycznych (Ef 2,11; 1 Tes 2,9; 2 P 3,1), zachęca adresatów do życia zgodnie z wcześniej przyjętymi zasadami lub do powrotu do ich praktykowania, a także do czynienia pokuty (zob. Łk 15,1734) Można powiedzieć, że pamięć o Bożych darach i dobrodziejstwa staje się najlepszą motywacją nawrócenia. Dlatego Duch Święty, przypominając tożsamość chrześcijan, wzywa jednocześnie do nawrócenia $(\mu \in \tau \alpha \nu$ ó $\sigma 0 \nu)$, to znaczy przede wszystkim do zmiany myślenia, gdyż użyte słowo greckie $\mu \in \tau \alpha \nu \circ \in ́ \omega$ oznacza przemianę wewnętrzną, umysłową ${ }^{36}$. Najogólniej mówiąc, chodzi o spojrzenie na swoje życie i toczącą się historię z nowej perspektywy samego Boga i tego wszystkiego, co On w swoje nieskończonej miłości uczynił i nadal czyni dla człowieka. Duch Święty wzywa zatem wspólnotę oraz pojedynczego wiernego, aby słuchając i przypominając sobie wielkie dzieła Boga, przyjmować zamysł i mentalność Boga ${ }^{37}$.

Postulowana wewnętrzna przemiana sposobu myślenia i pragnienia woli człowieka prowadzi do konkretnych czynów, które potwierdzają nawrócenie. Stąd trze-

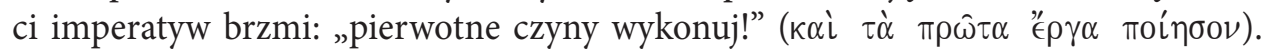
Chodzi więc o zmianę postępowania i powrót do pierwotnej miłości i gorliwego zaangażowania w praktykowanie wiary. Zdaniem Piotra Florencjana Szymańskiego "pierwotne czyny” dotyczą dawania żarliwego świadectwa rozumianego w trzech wymiarach: 1) świadectwo bliskości Jezusa $(2,1) ; 2)$ świadectwo miłości braterskiej (miłość nieprzyjaciół - 2,2-3); 3) świadectwo słowa (światło dla innych Kościołów i świata pogańskiego - pierwszy świecznik - 2,1 $)^{38}$.

Zdaniem komentatorów trzy imperatywy wypowiedziane do Kościoła przez Ducha Świętego opisują całościowo proces postulowanego nawrócenia ${ }^{39} \mathrm{i}$ odnoszą się do trzech niezbędnych etapów prawdziwej pokuty, to znaczy refleksji, żalu i napra-

Zob. Bogacz, Chrystusowe wskazania, 59. Na temat chrztu jako włączenia w misterium paschalne Jezusa zob. Podeszwa, „Wyprali swoje szaty”, 33-54.

Choć w tekście brakuje typowego czasownika odnoszącego się do pamięci, to jednak marnotrawny syn przypomniał sobie rodzinny dom, dostatek chleba w domu ojca i podjął decyzję pokuty i powrotu do ojca.

35 Zob. Tkacz, Listy do siedmiu Kościołów, 110.

36 Inaczej Wojciechowski, Apokalipsa, 129. Autor zauważa także, że grecka umysłowość rozumiała etykę jako wiedzę moralną.

37 Zob. Kiernikowski, Eucharystia, 279.

38 Szymański, „Czyny” $w$ dialogu homiletycznym, 109.

39 Prigent, L'Apocalypse, 121. 
$w y^{40}$. Warto zauważyć, że wezwanie do nawrócenia pojawia się w pierwszym Liście do Kościoła w Efezie, zatem na samym początku bezpośredniej mowy Jezusa i Ducha Świętego do Kościoła. Przywołuje to w pamięci bardzo wyraźnie początek działalności publicznej Jezusa i Jego pierwsze słowa wypowiedziane w Ewangelii: „Czas się wypełnił i nadchodzi już królestwo Boże! Nawracajcie się i wierzcie w Ewangelię" (Mk 1,15). Można zatem powiedzieć, że Duch Święty, który rozpoczyna mowę do Kościoła, na samym początku przypomina Jezusowe wezwanie do opartej na Dobrej Nowinie przemiany myślenia (nawrócenia) i postępowania (aktywnej wiary). Analogicznie teraz wspólnota efeska ma sobie przypomnieć dzieło zbawcze Jezusa (Ewangelię), zmienić sposób myślenia i wartościowania (nawrócenie) i konsekwentnie podjąć czyny, które są owocem przyjętej i wyznawanej wiary oraz potwierdzają jej autentyczność i żywotnośćt ${ }^{4}$. Ponieważ czas się wypełnił i nadeszło już Królestwo Boże (dzieło zbawcze dokonało się), wspólnota zostaje przynaglona do nawrócenia poprzez swoistego rodzaju sankcję: „,bo jeśli nie, to przyjdę do ciebie i przesunę twój świecznik z jego miejsca, jeśli się nie nawrócisz" $(2,5)$. Przestroga Jezusa świadczy, że wezwania do nawrócenia nie można zignorować, a jego zaniechanie będzie skutkowało usunięciem Kościoła efeskiego spośród wspólnot chrześcijańskich lub utratą przez niego „zdolności pełnienia funkcji duchowego przewodnictwa w stosunku do innych lokalnych Kościołów" ${ }^{\prime 2}$. Według Williama M. Ramsay’a nie chodzi tutaj o zniszczenie czy zagładę miasta, ale użycie czasownika kıv'́ $\omega$ jest zapowiedzią przenosin, nawiązującą do wielu zmian, które miały miejsce przy położeniu miasta ${ }^{43}$. Jezus zapowiadałby przesunięcie „świecznika ze swego miejsca”, które oznaczałoby, że Kościół efeski musiałby niejako rozpoczynać wszystko od nowa, od początku. W kontekście naszych analiz można uznać to za zapowiedź, że jeśli wspólnota okaże się opieszała w nawróceniu, sam Jezus przyjdzie i sprawi, że Kościół będzie musiał powrócić do swoich początków, do pierwotnej miłości i jej czynów, gdyż to jest warunkiem jego trwania w świecie.

Nawrócenie chrześcijan staje się więc stanowczym żądaniem Jezusa i Ducha Świętego. Taka odnowiona postawa potrzebna jest bardzo wspólnocie, zwłaszcza wobec problemów wewnętrznych, które sama przeżywa. Jezus chwali wyznawców w Efezie, że podobnie jak On sam, i oni nienawidzą czynów nikolaitów $(2,6)$. Nawet jeżeli trudno jednoznacznie odpowiedzieć na pytanie, kim byli wspominani nikola-

40 Jankowski, Apokalipsa, 148. Zdaniem Stephena S. Smalley'a (The Revelation, 61) trzy czasowniki opisują "the three stages in the history of conversion”. Jak zauważa Wojciechowski (Apokalipsa, 130), w starożytnym chrześcijaństwie zdanie to przyjmowano także jako potwierdzenie, że po grzechu i odstępstwie chrześcijanin ma szansę nawrócenia i powrotu do wspólnoty.

41 Alain-Marie de Lassus (L’Église, 57) pisze o nawróceniu teologalnym, obejmującym wiarę, nadzieję i miłość.

42 Sieg, Apokalipsa, 66.

43 Zob. Ramsay, The Letters to the Seven Churches, 244. Zob. także Tkacz, Listy do siedmiu Kościołów, 111. 
ici ${ }^{44}$, trzeba zauważyć, że ostrze krytyki nie jest wymierzone w samych nikolaitów, ale w ich postępowanie i czyny. Być może jest to subtelne przypomnienie wiernym, że nie można nienawidzić i potępiać grzeszników, ale tylko ich karygodne czyny. Samo użycie czasownika "nienawidzić", które służy wyostrzeniu obrazu ${ }^{45}$, wskazuje, że wspólnota, podobnie jak sam Jezus, powinna jednoznacznie odciąć się od czynów nikolaitów, gdyż nie są one do pogodzenia z wyznawaną wiarą chrześcijańską. Ostateczną motywacją ich odrzucenia jest fakt, że sam Jezus je potępia. Potrzebna jest więc wielka czujność wyznawców Jezusa, aby grzeszne czyny nikolaitów nie przenikały do życia wspólnoty, zatruwając i osłabiając ją wewnętrznie. Jezus nakazuje bezkompromisowe odcięcie się od zła i grzechu.

Taka jest wola Jezusa objawiona przez Ducha Świętego Kościołowi w Efezie, który „ma ucho”, to znaczy zdolność słuchania i rozumienia, dlatego powinien słyszeć, „co Duch mówi do Kościołów” (2,7) i być posłuszny wezwaniom Jezusa. List kończy się obietnicą dla zwycięzcy. Jezus pozwoli „mu jeść z drzewa życia, które jest w raju Boga" (2,7). Jak słusznie zauważa Waldemar Chrostowski:

określenie „Zwycięzca” pochodzi z terminologii wojskowej lub sportowej. Jedna i druga była doskonale znana chrześcijanom w Efezie. Apostoł Jan ma na myśli tych wyznawców Chrystusa, którzy wbrew wszystkim pokusom i przeciwnościom wytrwają przy zmartwychwstałym i uwielbionym Panu. Imieniem miłości jest wierność, która doczeka się nagrody, o której mowa w zakończeniu i epilogu Apokalipsy (rozdz. 21-22). „Drzewo życia” z utraconego ogrodu Eden to symbol życia w lasce, która uzdrawia chrześcijan i podtrzymuje Kośció $1^{46}$.

Zostali oni także wymienieni w Ap 2,14, gdzie Zmartwychwstały napomina wspólnotę, że są w niej chrześcijanie, którzy zamiast trwać przy Jezusie i nie zapierać się wyznawanej wiary $(2,13)$, trzymają się raczej „nauki Balaama” oraz „nauki nikolaitów”. Chodzi prawdopodobnie o udział niektórych chrześcijan w kulcie pogańskim i rozpuście oraz tolerowanie we wspólnocie pewnych poglądów, być może pochodzenia gnostyckiego. Wobec takich postaw chrześcijan, Jezus jednoznacznie wzywa wspólnotę do nawrócenia (2,16); zob. Wojciechowski, Apokalipsa, 130-131, 143-144; na temat nikolaitów i świadectw Ojców Kościoła, wspominających tę sektę, ale nie dających jednoznacznej odpowiedzi na temat ich pochodzenia oraz doktryny, zob. Sikora, „Zagrożenie jedności Kościoła”, 147-149; Kotecki, Kościół, 309-316; Dariusz Kotecki uważa, że „nikolaici reprezentują grupę chrześcijan, którzy myślą, że uczestnictwo w kulcie idolatrycznym tego miasta jest dozwolone i co więcej, tak czynią, aby nie pozbawić się wynikających z niego profitów. Może łączyli w ten sposób idolatrię tradycyjną z kultem cesarzy i idolatrią dóbr materialnych" (ibidem, 316). Często można spotkać się z opinią, że chodzi o jakąśs sektę o charakterze gnostyckim. Jednak, jak zauważa Roman Tkacz (Listy do siedmiu Kościołów, 113), źródła gnostyckie nie zawierają ani ich nazwy, ani nie przywiązują wagi do swobody seksualnej. Nie ma też wzmianek o spożywaniu mięsa ofiarowanego bożkom pogańskim. Znane jest natomiast przekonanie niektórych, że nikolaici to zwolennicy Pawła, gdyż podobnie jak on, ignorowali dekret apostolski tzw. Soboru Jerozolimskiego, zapisany w Dz 15; zob. Hilgenfeld, Die Ketzergeschichte, 220-226. To ostatnie odniesienie bibliograficzne zostało zacytowane za: Tkacz, Listy do siedmiu Kościołów, 114, przyp. 157. 


\section{Przypomnij sobie, jak wziąłeś... $(3,3)$}

Drugie odniesienie wprost do pamięci wspólnoty znajduje się w Liście do Kościoła w Sardach (3,1-6), miasta w starożytnej Anatolii, niegdyś stolicy Lidii. Jezus przedstawia się Kościołowi jako „Ten, który ma siedem Duchów Boga i siedem gwiazd” $(3,1)$. Określenia te symbolicznie oznaczają, że posiada On pełnię Ducha Świętego ${ }^{47}$ i jest Panem siedmiu Kościołów $(1,20)$, nad którymi roztacza swoją opiekę. Zna także doskonale sytuację wspólnoty w Sardach i ocenią ją dość surowo: „masz imię, które mówi, że żyjesz, lecz jesteś martwy" $(3,1)$. Imię $e^{48}$ chrześcijan wskazuje na ich przynależność do zmartwychwstałego Chrystusa $(1,17 ; 2,8)$, ale niestety ich wiara osłabła, stała się mierna i jałowa, stąd wspólnota została uznana przez Jezusa za martwą. Zdanie to przypomina nam Jk 2,17, gdzie mowa, że „wiara, która nie jest potwierdzona czynami, martwa jest sama w sobie”. Brakuje zatem konkretnych czynów miłości, które potwierdzają wyznawaną wiarę. Zdaniem Waldemara Chrostowskiego

napomnienie Apostoła ma na względzie nie tyle apostazję spowodowaną podatnością na uleganie kultowi imperialnemu, ile marazm duchowy podszyty złudnym poleganiem na sobie i wybiórczym przyswajaniem nauki Ewangelii. Bardzo prawdopodobne, że skutkiem bezpośredniego sąsiedztwa $\mathrm{z}$ bogatą wspólnotą wyznawców judaizmu postępowało osłabienie ducha chrześcijan, spotęgowane działalnością fałszywych proroków i oddziaływaniem tendencji judaizujących. Ostatni czynnik znajduje potwierdzenie w treściach homilii żyjącego kilkadziesiąt lat później biskupa Melitona z Sardes (zm. ok. 180 r.). Nie zostawiają one wątpliwości, że konfrontacja między wyznawcami Chrystusa a wyznawcami judaizmu ukształtowanego przez rabinów była bardzo zaogniona. Specyfika listu do Kościoła w Sardes polega na tym, że nie widać w nim śladów silnych konfliktów z Żydami ani poganami, z czego wniosek, że chrześcijanie utracili czujność niezbędną do ustrzeżenia swojej tożsamości ${ }^{49}$.

Cała wspólnota, a zwłaszcza jej przełożony, zostaje zatem wezwana najpierw do czujności i umocnienia „reszty, która miała umrzeć” $(3,2)$. Z wyrażenia tego wynika jednoznacznie, że nie wszyscy chrześcijanie w Sardach są już martwi, ale jest jeszcze jakaś grupa słabych i potrzebujących umocnienia w wierze. Można by ich porównać do biblijnej Reszty Izraela ${ }^{50}$, która ocalała, przetrwała próbę i ucisk oraz stała się zaczynem nowej przyszłości. Potrzebne jest więc odnowienie wiary znów owocującej dobrymi czynami, „bo nie znalazłem twych czynów doskonałymi przed Bogiem” $(3,2)$. Bogu zatem nie wystarczy połowiczność, oczekuje kompletności i doskonało-

\footnotetext{
47 Zob. Kotecki, Duch Święty, 240; Burnet, Le livre de l'Apocalypse, 114-115; inaczej Aune, Revelation, 219.

48 Zdaniem niektórych komentatorów chodzi o imię biskupa wspólnoty w Sardach; zob. Bogacz, Chrystusowe wskazania, 241. Jeśli przyjmiemy taką interpretację, to list nabiera charakteru bardzo osobistego i jest wezwaniem do nawrócenia zwłaszcza przełożonego wspólnoty.

49 Chrostowski, Entuzjazm, 77-78.

50 Zob. Jankowski, Apokalipsa, 157.
} 
ści ${ }^{51}$. Jeśli słowa te rozumiemy w pierwszym rzędzie jako skierowane do przełożonego wspólnoty, to staje się także jasne, że kryzys wspólnoty jest związany z brakiem należytej troski biskupa o stan religijny, duchowy i moralny powierzonych mu wiernych.

W takim kontekście pojawia się kolejne wezwanie: „Przypomnij sobie, jak wzią-

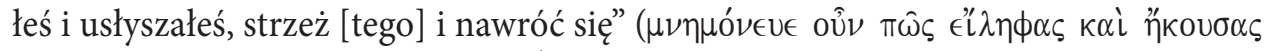

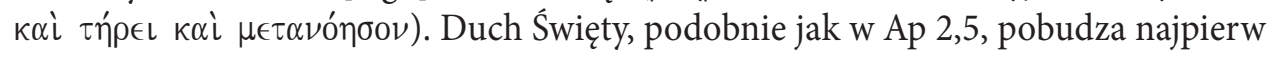
pamięć wspólnoty ( $\mu \nu \eta \mu o ́ v \epsilon \cup \epsilon)$. Wzywa, aby ta przypomniała sobie, to znaczy powróciła pamięcią do początków, kiedy to otrzymała Ewangelię (sakrament chrztu ${ }^{52}$ ). Chodzi o wspomnienie, które na nowo uobecni zarówno pierwotny entuzjazm, jak i zaangażowanie, towarzyszące wiernym w momencie przyjęcia Dobrej Nowiny. Chodzi więc o powrót do tego, co teraz osłabło, a nawet się gdzieś zatraciło. Ale w tym poleceniu zawarte jest także wezwanie do przypomnienia sobie tego wszystkiego, co jest istotne i fundamentalne dla wiary chrześcijańskiej, co stanowi jej treść (depozyt) ${ }^{53}$, co decyduje o tożsamości chrześcijan i odróżnia ich od wyznawców judaizmu oraz pogan. Podobnie jak w Ap 2,5 czasownik $\mu \nu \eta \mu 0 \nu \in \dot{\omega} \omega$ odnosi się do zasad moralnych i duchowych, akcentując ich niezmiennośćc ${ }^{54}$. Dlatego w 2 P 1,12-15 apostoł jest świadomy roli pamięci w życiu wspólnoty:

Dlatego zawsze wam będę przypominał, chociaż dobrze to wiecie i jesteście utwierdzeni w przyjętej prawdzie. Uważam jednak za słuszne wciąż wam o tym przypominać, dopóki jeszcze jestem w tym namiocie. Wiem, że bliskie jest zwinięcie mego namiotu, jak mi to oznajmił nasz Pan Jezus Chrystus. Będę się jednak starał, abyście nawet po moim odejściu zawsze o tym pamiętali.

Apostoł zachęca wspólnotę, aby zawsze pamiętała o słowach, które otrzymała i usłyszała. Zachowanie tej pamięci jest możliwe dzięki Duchowi pamięci. Warto tutaj przytoczyć doświadczenie Piotra zstąpienia Ducha Świętego na dom Korneliusza, o którym wspomina on w Jerozolimie:

Kiedy zacząłem przemawiać, Duch Święty zstąpił na nich, jak kiedyś na nas, na samym początku. Wtedy przypomniałem sobie słowa Pana: „Jan chrzcił wodą, wy zostaniecie ochrzczeni Duchem Świętym". Tak więc Bóg udzielił im tego samego daru, co nam, wierzącym w Pana Jezusa Chrystusa” (Dz 11,15-17).

To zstępujący Duch Święty pobudził pamięć Piotra, który przypomniał sobie słowa Jezusa, co z kolei pozwoliło mu poprawnie zinterpretować aktualne wydarzenie.

\footnotetext{
Zob. Wojciechowski, Apokalipsa, 156.

Zob. Szymański, „Czyny” w dialogu homiletycznym, 310, 312.

Zob. Sieg, Apokalipsa, 112.

Zob. Szymański, „Czyny” w dialogu homiletycznym, 309.
} 
Chrześcijanie mają sobie także na nowo uświadomić nie tylko zawartość (depozyt) Ewangelii, ale przypomnieć „jak wziąłeś” ( $\left.\pi \hat{\omega} \varsigma \epsilon^{\prime} \iota \lambda \lambda \eta \phi \alpha \varsigma\right)$, to znaczy, że Ewangelia została im darowana jako łaska, która przyszła od Boga przez wspólnotę Kościoła. Biorąc pod uwagę pierwotny sens przysłówka $\pi \hat{\omega} \varsigma$ w znaczeniu „jak”, wydaje się, że przedmiotem przypomnienia nie jest tylko depozyt Ewangelii, lecz początkowe wydarzenie związane z głoszeniem Dobrej Nowiny w Sardach ${ }^{55}$. Zdaniem Pierre’a Prigenta miało ono znamiona cudu, który zadecydował o zrozumieniu i przyjęciu Ewangelii ${ }^{56}$. Kolejny czasownik wskazuje natomiast na sposób jej otrzymania: „jak

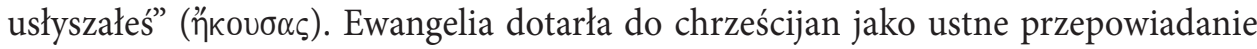
(zob. Rz 10,14.17) ${ }^{57}$. Być może w tym zawarta jest także aluzja do koniecznej troski o uważne słuchanie słowa Bożego oraz gorliwe głoszenie Ewangelii, aby mogła dotrzeć do wszystkich.

Otrzymana prawda Ewangelii stanowi skarb i depozyt, którego należy strzec ( $\tau \dot{p} \rho\llcorner)$, co zostaje wyrażone przy pomocy trybu rozkazującego czasu teraźniejszego, czyli jest to nakaz ciągle aktualny. Polecenie to wpisuje się w postulowaną postawę zachowania nieskażonego depozytu chrześcijańskiej wiary (2 Tes 2,15; $1 \mathrm{Tm} 6,20$; 2 Tm 1,12.14; Ef 2,19-20; 2 P 3,2 $)^{58}$. W kontekście naszych dociekań warto przytoczyć tekst 2 P 3,2: „Pamiętajcie ( $\mu \nu \eta \sigma \theta \eta \hat{\nu} \alpha \iota)$ słowa wypowiedziane kiedyś przez świętych proroków i przykazania naszego Pana i Zbawiciela, podane wam przez waszych apostołów". Autor zachęca wspólnotę, aby zawsze pamiętała o słowach, które otrzymała i usłyszała oraz o przykazaniach Jezusa. To wezwanie do zachowania pamięci jest równoznaczne z poleceniem strzeżenia tradycji i depozytu wiary. Warto także przypomnieć, że w Ap 12,17 chrześcijanie zostali określeni jako „ci, którzy strzegą przykazań Bożych oraz posiadają świadectwo Jezusa" ${ }^{59}$.

Ostatni imperatyw ${ }^{60}$ dotyczy nawrócenia ( $\left.\mu \epsilon \tau \alpha \nu o ́ \eta \sigma o \nu\right)$. Skoro pobudzona zostaje pamięć wspólnoty, która przypomina dobrodziejstwa wiary chrześcijańskiej, to jest ona najlepszą motywacją do postulowanego nawrócenia, to znaczy nowego sposobu myślenia oraz towarzyszącej mu przemiany postępowania. Nie chodzi tylko o podjęcie pierwszych czynów, ale także takich, których wymaga zmieniająca się sytuacja egzystencjalna wyznawców Chrystusa, zawsze jednak w wierności Ewangelii i własnej tożsamości uczniów Jezusa. Jezus zapowiada, że jeśli dokona się oczekiwane nawrócenie, nastąpi niespodziewane przyjście „jak złodziej” $(3,3)$.

Na szczęście we wspólnocie w Sardach jest grupa wierzących, którzy pozostali czyści i zachowali wierność Jezusowi, co symbolicznie zostało wyrażone w stwier-

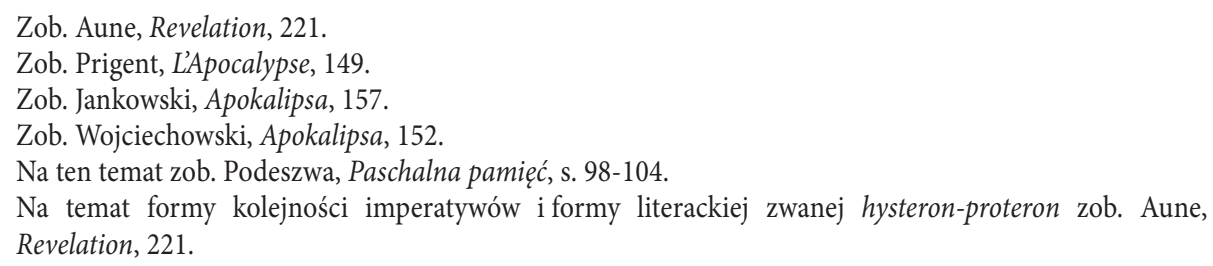


dzeniu, że nie splamili swoich szat i będą chodzili z Chrystusem w bieli, bo są tego godni (zob. 3,4). Jak zauważa Waldemar Chrostowski:

W Sardes istniała niewielka, lecz widoczna grupa chrześcijan, których życie i postępowanie pozostało nieskażone, co pozwalało żywić nadzieję, iż nie wszystko stracone. Nawet gdy przełożeni nie sprostają powierzonej im roli, znajdą się wyznawcy, którzy ustrzegą wierności Ewangelii, ponieważ będą przy niej niezłomnie trwali i staną się zadatkiem duchowego odrodzenia ${ }^{61}$.

Podobnie brzmi także obietnica dla zwycięzcy, któremu Jezus zapowiada: „będzie nosił białe szaty i nie wymażę jego imienia z księgi życia. Imię jego wyznam przed moim Ojcem i przed Jego aniołami” $(3,5)$. List kończy się znaną nam już formułą: „Kto ma ucho, niech usłyszy, co Duch mówi do Kościołów” $(3,6)$.

\section{Duch Święty mocą pobudzającą pamięć Kościoła}

Przeanalizowane dwa teksty z Apokalipsy Janowej wyraźnie wskazuję na szczególną rolę Ducha Świętego i pozwalają nazwać Go „żywą pamięcią Kościoła” (KKK 1099) oraz „tchnieniem aktualizującym przeszłość”62. To właśnie Paraklet, zgodnie z obietnicą Jezusa, działa w Kościele, pobudzając i aktywizując pamięć wspólnoty. W ten sposób zmartwychwstały Jezus jest nieustannie obecny w Kościele, prowadzi go, troszczy się o niego, kierując słowa zachęty, ostrzeżenia, wezwania do nawrócenia, odnawiając obietnice dla zwycięzców ${ }^{63}$. Zadaniem Ducha jest między innymi nieustanne przypominanie Pierwszego Parakleta, co oznacza, że chodzi nie tylko o przywoływanie w pamięci dawnych wydarzeń, ale ukazywanie ich pełnego sensu i aktualizowanie ich w życiu wspólnoty. Obrazowo można by powiedzieć, że słowa Jezusa, jak „nasiona”, zostały złożone w sercach wierzących, a „woda” Ducha Świętego pozwala im kiełkować, rozwinąć się, rosnąć i wydawać plony, umożliwiając jednocześnie dostrzeżenie ich piękna i głębi ${ }^{64}$. Paraklet kontynuuje objawienie Jezusa, wyjaśnia je Kościołowi oraz jest ostatecznym Interpretatorem orędzia Chrystusowego. Dzięki Niemu słowo Jezusa jest ciągle słyszalne i rozbrzmiewa we wspólnocie (por. KO 8), a Jego wola wyznacza sposób życia i działania poszczególnych wyznawców Jezusa oraz Kościoła jako wspólnoty wierzących.

\footnotetext{
61 Chrostowski, Entuzjazm, 80.

62 Cothenet, Exégèse, 203.

63 Zob. Cothenet, Exégèse, 202, 209.

64 Zob. Léon-Dufour, „Spécificité symbolique”, 122.
} 
Rolą Ducha jest zachowanie w pamięci wspólnoty czynów i słów Jezusa, gdyż przypominanie Tego, który już przyszedł w przeszłości, jest koniecznym warunkiem rozpoznania i usłyszenia Tego, który nieustannie przychodzi (zob. Ap 1,7). To aktualizujące wspominanie jest jak odsłanianie twarzy Przychodzącego ${ }^{65}$. Paraklet, będący anamnezą Jezusa i „retrospekcją” wcielonego i paschalnego Chrystusa, nie tylko uczy rozumieć i zachowywać fundacyjną historię wiary chrześcijańskiej i jej wyznawców, ale pozwala odszyfrować teraźniejszość wspólnoty oraz ukierunkować ku przyszłości, która otwiera się przed wierzącymi ${ }^{66}$.

Analizowane teksty, w których Duch Święty wzywa wspólnotę Kościoła do pobudzenia pamięci, wyraźnie wskazują, że chodzi przede wszystkim o przypomnienie fundamentów chrześcijańskiej wiary (Wcielenie, misterium paschalne) oraz tożsamości chrześcijan złączonych przez chrzest z ukrzyżowanym i zmartwychwstałym Jezusem i zrodzonych do nowego życia. Wezwanie do pamiętania jest równoznaczne z koniecznością gorliwego strzeżenia depozytu wiary oraz nawracania się, to znaczy przyjmowania mentalności i zamysłu samego Boga. Pamiętanie będzie następnie owocowało konkretnymi czynami wiary. Motywacją do takiej postawy chrześcijan jest pamięć o dobrodziejstwach i darach Boga. Duch Święty, pobudzając i aktywując pamięć Kościoła, mobilizuje do żywej i owocującej wiary, która wyraża się w prawdziwym chrześcijańskim świadectwie przynależności do Jezusa, braterskiej miłości oraz gorliwości w głoszeniu Dobrej Nowiny.

Wezwanie z zakończenia siedmiu listów Apokalipsy, aby „mieć ucho” i słuchać tego, co „Duch mówi do Kościołów”, pozostaje ciągle aktualne i stanowi konieczną postawę uczniów Jezusa. Tylko Kościół zasłuchany w słowa Jezusa, słyszalne dzięki Duchowi Świętemu ${ }^{67}$, nie utraci swojej tożsamości i nie zapomni o tym, co fundamentalne i istotne. Tylko Kościół otwarty i wyczulony na działanie Parakleta rozpozna przychodzącego Pana, odnajdzie sens tego, co przeżywa i z czym się zmaga każdego dnia. Tylko Kościół pamiętający i mocą Parakleta nieustannie przypominający sobie o Bożych dobrodziejstwach będzie praktykował z entuzjazmem czyny „pierwszej miłości” Boga i człowieka oraz wiernie wypełni swoje posłannictwo względem Boga i świata, który dzięki chrześcijanom ma zostać przemieniony i ubogacony pięknem Jezusowej Ewangelii.

\footnotetext{
65 Zob. Zumstein, „La memoire créatrice”, 322.

66 Zob. Zumstein, „La memoire créatrice”, 323.

67 Zob. Szamot, Apokalipsa, 310-311.
} 


\section{Bibliografia}

Aune, D.E., Revelation 1-5 (WBC 52; Nashville, TN: Nelson 1997).

Biguzzi, G., „I numeri nell’Apocalisse di Giovanni e il loro linguaggio”, Liber Annuus 50 (2000) 143-166.

Bogacz, R., Chrystusowe wskazania na czas próby. List do siedmiu Kościołów Apokalipsy (Kraków: Uniwersytet Papieski Jana Pawła II 2015).

Burnet, R., Le livre de l'Apocalypse (Paris: Cerf 2019).

Chrostowski, W., Entuzjazm i sprzeciw wobec Chrystusa. Listy do Siedmiu Kościołów Apokalipsy (Kraków: Biały Kruk 2019).

Corsini, E., „I numeri nell'Apocalisse”, Apokalypsis. Percorsi nell'Apocalisse in onore di Ugo Vanni (red. E. Bosetti - A. Colacrai) (Assisi: Cittadella 2005) 391-416.

Cothenet, E., Exégèse et liturgie (Paris: Cerf 1999) II.

Díez Merino, L., „La numerología en el Apocalipsis: un principio de hermenéutica”, Ciencia Tomista 127 (2000) 59-98.

Hilgenfeld, A., Die Ketzergeschichte des Urchristentums (Hildesheim: Olms 1963).

Jankowski, A., Apokalipsa św. Jana. Wstęp - przekład z oryginału - komentarz (Poznań: Pallottinum 1959).

Karczewski, M., „Wytrwałość chrześcijan w Liście do Kościoła w Efezie (Ap 2,1-6)”, Przybliżyło się Królestwo Boże. Księga pamiątkowa dla Księdza Profesora Romana Bartnickiego w 65. rocznice urodzin (red. W. Chrostowski) (Warszawa: Stowarzyszenie Biblistów Polskich 2008) 192-204.

Kempiak, R., „Pneumatologia”, Teologia Nowego Testamentu. II. Dzieło Janowe (red. M. Rosik) (Wrocław: Tum 2008) 83-158.

Kiernikowski, Z., Eucharystia i jedność (Częstochowa: Tygodnik Katolicki „Niedziela” 2000).

Kotecki, D., Duch Święty w zgromadzeniu liturgicznym w świetle Apokalipsy św. Jana (Warszawa: Vocatio 2006).

Kotecki, D., Kościót w świetle Apokalipsy św. Jana (Częstochowa: Edycja Świętego Pawła 2008).

Kotecki, D., „ «List do Kościoła w Laodycei» (Ap 3,14-21) w świetle hermeneutycznego klucza objawieniowo-liturgicznego", Credidimus caritati. Księga pamiątkowa dedykowana księżom profesorom Ryszardowi Figlowi $i$ Tadeuszowi Haneltowi $w 70$. rocznice urodzin (red. M. Olczyk - P. Podeszwa) (Gniezno: Prymasowskie Wyższe Seminarium Duchowne 2010) 239-263.

de Lassus, A.-M, L'Église à l'écoute de l'Esprit (Paris: Salvator 2016).

Léon-Dufour, X., „Spécificité symbolique du langage de Jean”, La Communauté johannique et son histoire: la trajectoire de l'Évangile de Jean aux deux premiers siècles (red. J.-D. Kaestli J.-M. Poffet - J. Zumstein) (Genève: Labor et Fides 1990) 121-134.

Lijka, K., „Dzień Pański według Apokalipsy”, Liturgia Sacra 3/2 (1997) 33-39.

Manunza, C., L'Apocalisse come "actio liturgica" cristiana: Studio esegetico-teologico di Ap 1,9-16; 3,14-22; 13,9-10; 19,1-8 (Roma: Gregorian \& Biblical Press 2012).

Marconi, N., Le mille immagini dell'Apocalisse. Una introduzione al linguaggio audiovisivo dell'Apocalisse (Milano: Paoline 2002).

Moriconi, B., Lo Spirito e le Chiese. Saggio sul termine "pneu/ma» nel libro dell'Apocalisse (Roma: Teresianum 1983). 
Podeszwa, P., Paschalna pamięć o Jezusie. Studium egzegetyczno-teologiczne wyrażenia

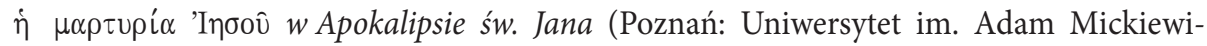
cza 2011).

Podeszwa, P., „Il simbolismo della cifra dieci nell'Apocalisse di San Giovanni”, Biblica et Patristica Thoruniensia 5 (2012) 85-101.

Podeszwa, P., „«Temu, który nas miłuje» (Ap 1,5). Miłość Chrystusa do Kościoła w świetle wybranych tekstów z Apokalipsy św. Jana”, Teologia Praktyczna 16 (2015) 95-110.

Podeszwa, P., „Wspólnota Kościoła w świetle Apokalipsy św. Jana”, Mowa świątyni (red. R. Dublański) (Wrocław: Tum 2012) 55-69.

Podeszwa, P., „Wyprali swoje szaty i wybielili je we krwi Baranka (Ap 7,14). Chrzest według Apokalipsy świętego Jana”, Studia Bydgoskie 7 (2013) 33-54.

Popowski, R., Wielki słownik grecko-polski Nowego Testamentu wydanie z pełna lokalizacja haseł, kluczem polsko-greckim oraz indeksem form czasownikowych (Warszawa: Vocatio 1995).

Pottier, B. - Struyf, D., „Lettres aux Églises (Ap 2-3): maladies psychiques et spirituelles des groupes", Nouvelle Revue Théologique 138/4 (2016) 549-567.

Prigent, P., L'Apocalypse de Saint Jean (Genève: Labor et Fides 2000).

Ramsay, W.M., The Letters to the Seven Churches of Asia and Their Place in the Plan of the Apocalypse, wyd. 2 (Peabody, MA: Hendrickson 2001).

Sieg, F., Apokalipsa św. Jana. Listy do siedmiu Kościołów (Ap 1-3), wyd. 2 (Pelplin: Bernardinum 2009).

Sikora, R.A, „ «[..] odstąpiłeś od twej pierwotnej miłości» (Ap 2,4)”, Roczniki Teologiczne 45/1 (1998) 167-179.

Sikora, A.R., „Zagrożenie jedności Kościoła według Ap 2-3”, Biblia podstawa jedności (red. A.R. Sikora) (Lublin: Redakcja Wydawnictw KUL 1996) 147-149.

Smalley, S.S., The Revelation to John (Downers Grove, IL: InterVarsity Press 2005).

Szamot, M., Apokalipsa czytana dzisiaj (Kraków: WAM 2000).

Szymański, P.F., „Czyny” $w$ dialogu homiletycznym według Listów do siedmiu Kościołów Księgi Apokalipsyśw. Jana (Ap 2-3). Studium egzegetyczno-homiletyczne (Toruń: Marszałek 2011).

Tkacz, R., Listy do siedmiu Kościołów (Ap 2,1-3,22). Studium historyczno-egzegetyczne (Warszawa: Vocatio 2003).

Wojciechowski, M., Apokalipsa świętego Jana. Objawienie, a nie tajemnica (Częstochowa: Edycja Świętego Pawła 2012).

Zbroja, B., „Symbolika arytmetyczna Apokalipsy”, Inkulturacja Biblii (red. T. Jelonek) (Kraków: Wydawnictwo Naukowe PAT 2007) 131-158.

Zumstein, J., „La memoire créatrice des premiers chrétiens”, Memory and Memories in Early Christianity: Proceedings of the International Conference Held at the Universities of Geneva and Lausanne (June 2-3, 2016) (red. S. Butticaz - E. Norelli) (Tübingen: Mohr Siebeck 2018) 313-325. 
